\title{
Oxidációs eljárások összehasonlítása neonikotinoid növényvédő szerek modelloldatokból történő eltávolítására
}

\section{Comparison of oxidation procedures for removing neonicotinoid insecticides from model solutions}

\author{
A. TRUZSI ${ }^{1}$, M. SZMOLKA 2 , I. BODNÁR ${ }^{3}$, J. VARGA ${ }^{4}$ \\ ${ }^{1}$ Debreceni Egyetem, Műszaki Kar, Környezetmérnöki Tanszék, IMSYS Mérnöki Szolgáltató Kft., \\ truzsi.alexandra@eng.unideb.hu \\ ²Debreceni Egyetem, Műszaki Kar, Környezetmérnöki Tanszék, szmolkamonika@gmail.com \\ ${ }^{3}$ Debreceni Egyetem, Műszaki Kar, Környezetmérnöki Tanszék, bodnari@eng.unideb.hu \\ 4IMSYS Mérnöki Szolgáltató Kft., varga.jozsef@imsys.hu
}

Absztrakt. Kutatásaink során három neonikotinoid típusú növényvédô szer hatóanyag (thiametoxam, acetamiprid, thiakloprid) eltávolítását tüztük ki célul modelloldatokból ferrát és perszulfát alapú oxidációs eljárások alkalmazásával. Kísérleteink során a célvegyületek meghatározására HPLC-MS/MS kapcsolt méréstechnikával analitikai módszert dolgoztunk ki, majd vizsgálatokat végeztünk annak megállapítására, hogy a kiindulási célvegyület/oxidálószer mólaránya hogyan befolyásolja a célkomponensek eltávolításának mértékét.

Abstract. The main objective of this study is to remove three neonicotinoid insecticide agents (thiametoxam, acetamiprid, thiakloprid) from model solutions using ferrate and persulfate-based oxidation techniques. In our experiments, an analytical method was developed for HPLC-MS/MS coupled techniques and tests were performed to determine how the molar ratio of the starting target compound/oxidant affects the degree of removal of the target components.

\section{Bevezetés}

A kutatás témájául választott neonikotinod típusú növényvédő szereket nagy mennyiségben alkalmazzák a mezőgazdasági haszonnövények termelésében rovarölő szerekként. Ezek a vegyületek a természeti környezetben nehezen bomlanak le, ott hosszan megmaradhatnak [1]. A célcsoportra való hatásuk mellett kimutatták a méhekre gyakorolt káros hatásukat is [2]. Az elmúlt évtizedekben történt kiterjedt alkalmazásaik miatt napjainkban ezek a vegyületek a növényvédő szer maradványok hatásaira irányuló vizsgálatok középpontjába kerültek [3]. A környezetbe jutva ezek a készítmények megmaradhatnak a talajban, a talaj kémiai összetételétől függően a talajvízbe is bekerülhetnek [4]. Bizonyított, hogy a neonikotinoidok károsíthatják az egészséget és a környezetet, ezért elszivárgásuk 
és környezetbeli jelenlétük jelentősen ronthatja a felszíni vizek, illetve a többi vizes élőhely minőségét. Emellett komoly problémákat okozhatnak az ivóvízkezelési eljárásokban is [5].

Az ilyen szennyeződések eltávolítására, vagy a koncentrációjuknak a csökkentésére különböző tisztítási technológiákat alkalmaznak (adszorpciós kezelések, membránszeparációs technikák, oxidatív, advanced oxidation processes (AOPs) kezelések és ezek kombinációja). Az egyik ilyen eljárás az oxidáció általi víztisztítás (kezelés $\mathrm{H}_{2} \mathrm{O}_{2}$-dal, UV besugárzás, UV $/ \mathrm{H}_{2} \mathrm{O}_{2}$ kombinált alkalmazása, ozonizálás, vagy $\mathrm{UV} / \mathrm{O}_{3}$ kombinált kezelések, perszulfátok alkalmazása, ferrát használata, stb.), mely hatékonyságának köszönhetően széles körben alkalmazott [6]. Kutatómunkánk során három neonikotinoid típusú növényvédő szer hatóanyag (thiametoxam, acetamiprid, thiakloprid) ferráttechnológiával és aktivált kálium-perszulfáttal történő oxidációját tanulmányoztuk HPLC-MS/MS kapcsolt analitikai méréstechnikával.

\section{Anyag és módszer}

\subsection{Az alkalmazott oxidálószerek bemutatása}

\subsubsection{Ferrát (VI) tulajdonságai}

A ferrátban a vas +6-os oxidációs állapotban van, ezért rendkívül erős oxidálószer (redoxipotenciálja savas közegben +2,2V). A ferrát-technológia előnye, hogy melléktermékként vas(III)-hidroxid csapadék keletkezik, mely nagy fajlagos felületének köszönhetően megköti az oxidációs bomlástermékeket és további szennyezőket, javítva ezzel a tisztítás hatékonyságát [7]. Míg a ferrát pH=9 érték felett képes órákig stabil maradni, addig ez alatti pH értékeken gyorsan - néhány másodperc és néhány perc közt változó időtartam alatt - elbomlik. A pH csökkentésével a ferrát protonált formái jelennek meg és a bomlás sebessége nő. A ferráttal végzett eddigi vizsgálatok azt bizonyítják, hogy az egyszeresen protonált forma a legreaktívabb, több kinetikai tanulmány szerint ez az ionforma játszik kiemelt szerepet az oxidációs/fertőtlenítési folyamatokban [8]. A ferrát (VI)-ion előállítása történhet elektrokémiai vagy kémiai módszerrel (száraz és nedves oxidációs eljárás). A kutatás során felhasznált ferrátot elektrokémiai módszerrel állították elő, lúgos közegben vas anód oxidációjával [9].

\subsubsection{Perszulfát alkalmazása a környezetvédelmi célú kutatások során}

A perszulfát $\left(\mathrm{S}_{2} \mathrm{O}_{8}{ }^{2}\right)$ anion hasonló fizikai-kémiai tulajdonságú három sója, az ammónium-perszulfát, a nátrium-perszulfát és a kálium-perszulfát. A perszulfát anion erős oxidálószer, standardpotenciálja +2,1 V. Azonban a perszulfát aniont aktiválva valamilyen katalizátorral, szulfát-gyököket képezve a standardpotenciálja savas közegben $+2,6 \mathrm{~V}$ lesz, ami nagyobb, mint a ferrát (VI)-é. A maximális standard redoxipotenciáljának elérése érdekében valamilyen fizikai-kémiai művelettel - pl.: hővel, átmeneti fémmel (leggyakrabban $\mathrm{Fe}^{2+}$ ), UV fénnyel - aktiválni kell (1-4.egyenletek).

$$
\begin{array}{ll}
\mathrm{S}_{2} \mathrm{O}_{8}^{2-}+\text { hő } \rightarrow 2 \mathrm{SO}_{4}^{-*} & \mathrm{E}_{0}=2,6 \mathrm{~V} \\
\mathrm{~S}_{2} \mathrm{O}_{8}^{2-}+\mathrm{UV} \rightarrow 2 \mathrm{SO}_{4}^{-*} & \mathrm{E}_{0}=2,6 \mathrm{~V}
\end{array}
$$


International Journal of Engineering and Management Sciences (IJEMS) Vol. 4. (2019). No. 2

DOI: 10.21791/IJEMS.2019.2.11.

$$
\begin{array}{ll}
\mathrm{S}_{2} \mathrm{O}_{8}^{2-}+\mathrm{Fe}^{2+} \rightarrow \mathrm{SO}_{4}^{-*}+\mathrm{Fe}^{3+}+\mathrm{SO}_{4}^{2-} & \mathrm{E}_{0}=2,6 \mathrm{~V} \\
\mathrm{~S}_{2} \mathrm{O}_{8}^{2-}+\mathrm{H}_{2} \mathrm{O} \rightarrow \mathrm{SO}_{4}^{2-}+\mathrm{OH}^{*}+\mathrm{H}^{+} & \mathrm{E}_{0}=2,7 \mathrm{~V}
\end{array}
$$

Az aktiváló folyamatok során a perszulfát anionból szulfát gyök és vízzel való reakciója során pedig hidroxilgyök keletkezik az 1-4. reakcióegyenletek szerint. Az aktiváló műveletek során az alkalmazott kémhatásnak kiemelt jelentősége van, mivel $\mathrm{pH}<7$ értéknél a szulfát gyökök, $\mathrm{pH}>9$-nél a hidroxilgyökök és pH=7-9 közt pedig mindkét gyök részt vesz az oxidációs folyamatban [10].

\subsection{Műszeres analitikai kémiai módszerek}

Kísérleteink során a kiválasztott peszticidek meghatározására tömegspektrometriás detektáláson alapuló folyadékkromatográfiával kapcsolt (HPLC-MS/MS) méréstechnikát alkalmazó analitikai módszert dolgoztunk ki.

\begin{tabular}{|l|l|}
\hline Ionforrás: & ESI (Electrospray Ionization) \\
\hline Adatgyűjtés típusa: & Dynamic MRM \\
\hline Polaritás: & Pozitív \\
\hline Köpeny gáz: & $15 \mathrm{psi}$ \\
\hline Kapilláris feszültség: & $4000 \mathrm{~V}$ \\
\hline Szárító gáz hőmérséklet: & $300^{\circ} \mathrm{C}$ \\
\hline Szárító gáz áramlási sebessége & $15 \mathrm{l} / \mathrm{min}$ \\
\hline Injektálási térfogat: & $1 \mu \mathrm{L}$ \\
\hline Oszlophőmérséklet: & $35^{\circ} \mathrm{C}$ \\
\hline Szoftver: & MassHunter B.08.02 \\
\hline
\end{tabular}

1. táblázat HPLC/MS/MS mérési körülmények

A kifejlesztett HPLC-MS/MS módszerrel lehetőségünk volt a kolonnán elválasztott neonikotinoid hatóanyagok meghatározására, illetve a különböző oxidatív módszerek alkalmazásával a célvegyületek koncentráció-változásának vizsgálatára is. A műszeres analitikai vizsgálatokhoz alkalmazott mérési

\begin{tabular}{|c|c|c|c|}
\hline Kolonna & \multicolumn{3}{|c|}{ Agilent ZORBAX Eclipse Plus C18, 2.1 x 50mm, $1.8 \mu \mathrm{m}$} \\
\hline A eluens & \multicolumn{3}{|c|}{ 0,1 V/V\% hangyasav + ionmentes víz } \\
\hline B eluens & \multicolumn{3}{|c|}{ Acetonitril } \\
\hline Idő (perc) & $\begin{array}{c}\text { Áramlási sebesség } \\
(\mathrm{ml} / \text { perc })\end{array}$ & $A(\%)$ & B (\%) \\
\hline 0.00 & 0.4 & 95 & 5 \\
\hline 5.00 & 0.4 & 5 & 95 \\
\hline 5.01 & 0.4 & 95 & 5 \\
\hline 10.00 & 0.4 & 95 & 5 \\
\hline
\end{tabular}
paraméterek az 1. és 2. táblázatban láthatóak.

2. táblázat A kromatográfiás mérés paraméterei 


\section{Eredmények és értékelésük}

\subsection{Ferráttal végzett oxidatív kezelések eredménye}

A ferráttal történő oxidatív kezelés során a készített modelloldatok térfogata $100 \mathrm{ml}$ volt, amik a neonikotinoidokat $1 \mathrm{ppm}$ koncentrációban tartalmazták. A kezelést a hatóanyagokat egyenként tartalmazó modelloldatokkal hajtottuk végre. A szükséges ferrát mennyiségét úgy számoltuk ki, hogy a neonikotinoid/ferrát mólarány 1:1, 1:2, 1:3, 1:4 és 1:5 legyen (3. táblázat).

\begin{tabular}{|l|c|}
\hline \multirow{4}{*}{ Közeg } & $150 \mathrm{mg} / \mathrm{l} \mathrm{NaHCO}_{3}$ \\
\hline \multirow{3}{*}{$\begin{array}{l}\text { Mólarány } \\
\text { neonikotinoid:Fe(VI) }\end{array}$} & $1: 1$ \\
\cline { 2 - 2 } & $1: 2$ \\
\cline { 2 - 2 } & $1: 3$ \\
\cline { 2 - 2 } & $1: 4$ \\
\hline Kezelés kémhatása & $1: 5$ \\
\hline Kezelési idő & $\mathrm{pH}=7$ \\
\hline HPLC-MS/MS & 30 perc keverés + 30 perc ülepítés \\
\hline
\end{tabular}

3. táblázat A ferrátkezelés kísérleti körülményei

Az elektrokémiai úton elő́llított ferrát erősen lúgos, így az adagolást követően a modellminták semleges kémhatásának beállításához 5 M-os kénsav oldatot használtunk. A modelloldatokat mágnesen keverővel kevertettük, amihez üveg bevonatú mágneses keverőelemet használtunk. A kezelési idő 30 perc volt szobahőmérsékleten, majd 30 percig ülepítettük a rendszert. A ferráttal végzett oxidatív kezelésen átesett minták egy membrán szűrőn $(0,45 \mu \mathrm{m} \emptyset)$ történő szűrést követően kerültek meghatározásra. Minden mérési adat három injektálás átlagolt mérési eredménye. A ferrátkezelés körülményeit a 3. táblázat részletezi.

A ferráttal végzett kezelések során a legnagyobb mértékben - 42,88 \%-os hatékonysággal - a thiakloprid hatóanyagot sikerült eltávolítani a célvegyületet külön-külön tartalmazó oldatokból. Ennél az eltávolítási hatékonyságnál az alkalmazott thiakloprid/ferrát mólarány 1:4 volt (1. ábra). A thiametoxam hatóanyagot a modelloldatokból 24,62 \%-os hatékonysággal sikerült oxidálni. Ennél az eltávolítási hatékonyságnál az alkalmazott thiametoxam/ferrát mólarány 1:1 volt. A modellkísérletek során minden esetben az acetamiprid hatóanyag eltávolítása volt a legkisebb mértékű, itt 1:5 mólarány mellett sikerült a legnagyobb eltávolítási hatásfokot elérni.

Tapasztalataink alapján megállapítható, hogy a hatóanyagok kémiai szerkezetétől függőn más-más mólarányok alkalmazása bizonyult hatékonynak az oxidációs kezelésekben, illetve rámutattunk arra is, hogy a ferrát a várttól eltérően nem mutatott kellő mértékű eltávolítási hatásfokot. 
International Journal of Engineering and Management Sciences (IJEMS) Vol. 4. (2019). No. 2

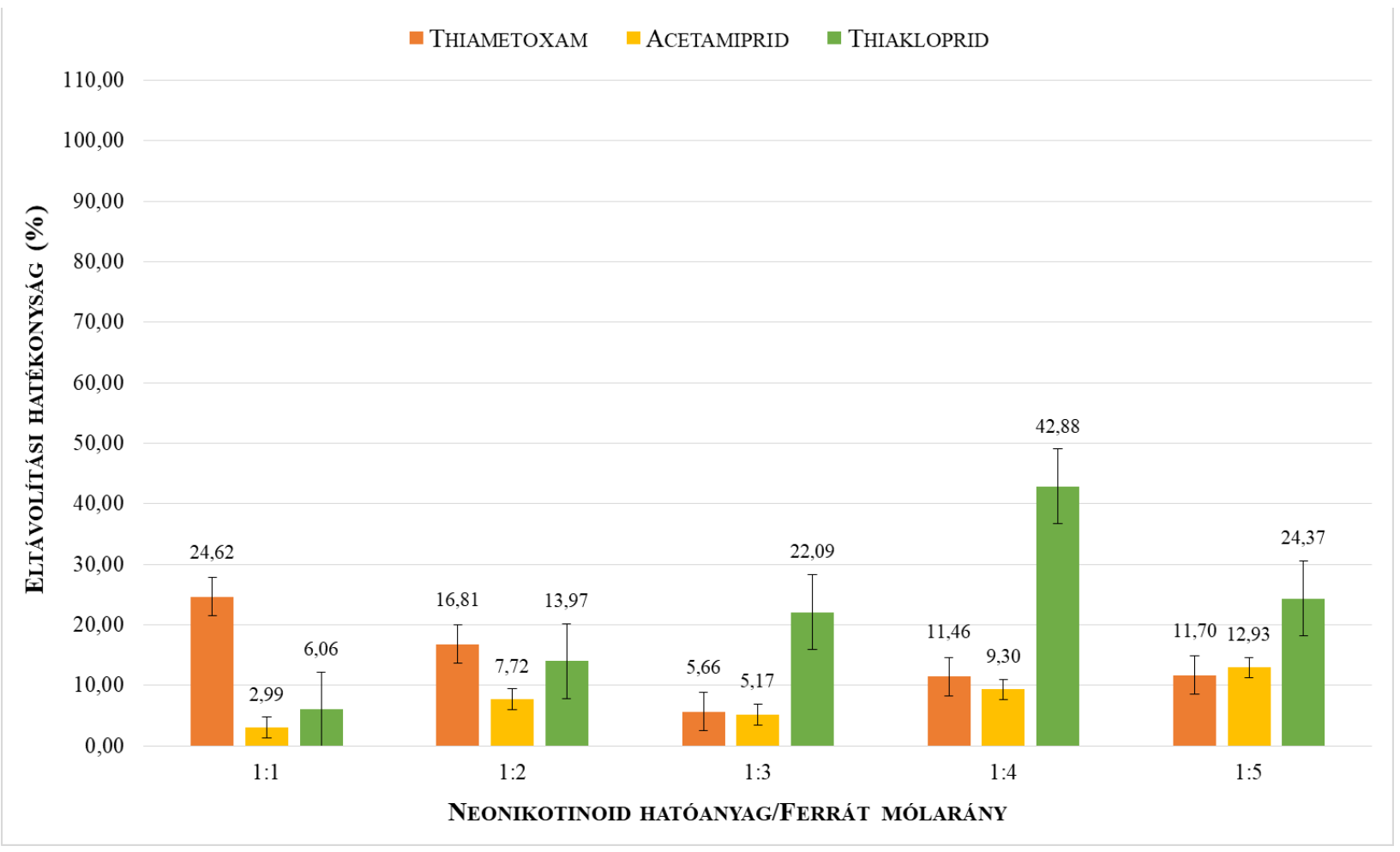

1. ábra Neonikotinoid hatóanyagok eltávolitási hatásfoka ferráttal végzett kezelések után

\subsection{Perszulfáttal végzett oxidatív kezelések eredménye}

A kísérletsorozat során 1 ppm neonikotinoid koncentrációjú $100 \mathrm{ml}$ térfogatú modelloldatokat kezeltünk Fe(II)-ionnal aktivált kálium-perszulfáttal. A kezelést szintén a neonikotinoidokat egyenként tartalmazó modelloldatokkal hajtottuk végre. A kísérletekhez $5 \mathrm{~g} / \mathrm{l}$-es kálium-perszulfát oldatot és aktiváló ágensként 2,27 mM koncentrációjú Fe(II) oldatot készítettünk. Az alkalmazott neonikotinoid/Fe(II)/perszulfát mólarányok: 1:15:20, 1:15:30, 1:15:40, 1:15:50 és 1:20:50 (4. táblázat).

\begin{tabular}{|l|c|}
\hline \multirow{4}{*}{$\begin{array}{l}\text { Mólarány } \\
\text { neonikotinoid:Fe(II):perszulfát }\end{array}$} & $1: 15: 20$ \\
\cline { 2 - 2 } & $1: 15: 30$ \\
\cline { 2 - 2 } & $1: 15: 40$ \\
\cline { 2 - 2 } & $1: 15: 50$ \\
\hline Kezelés kémhatása & $1: 20: 50$ \\
\hline Kezelési idő & pH=7 \\
\hline HPLC-MS/MS & 30 perc keverés \\
\hline
\end{tabular}

4. táblázat A perszulfáttal végzett oxidatív kezelés kísérleti körülményei

A modellmintákat mágneses keverővel kevertettük, melyhez teflon bevonatú mágneses keverőelemet használtunk. A kezelési idő (30 perc) elteltével azonnal mintát vettünk analízishez. Minden megadott adat három injektálás átlagolt mérési eredménye. 
A kezelések eredményeképpen megállapítottuk, hogy a perszulfáttal végzett kezelések során a thiakloprid, acetamiprid, thiametoxam hatóanyagok példáján vizsgálva a Fe(II)-ion hatékony katalizátor szerepét tölti be az oxidációs kezelésekben.

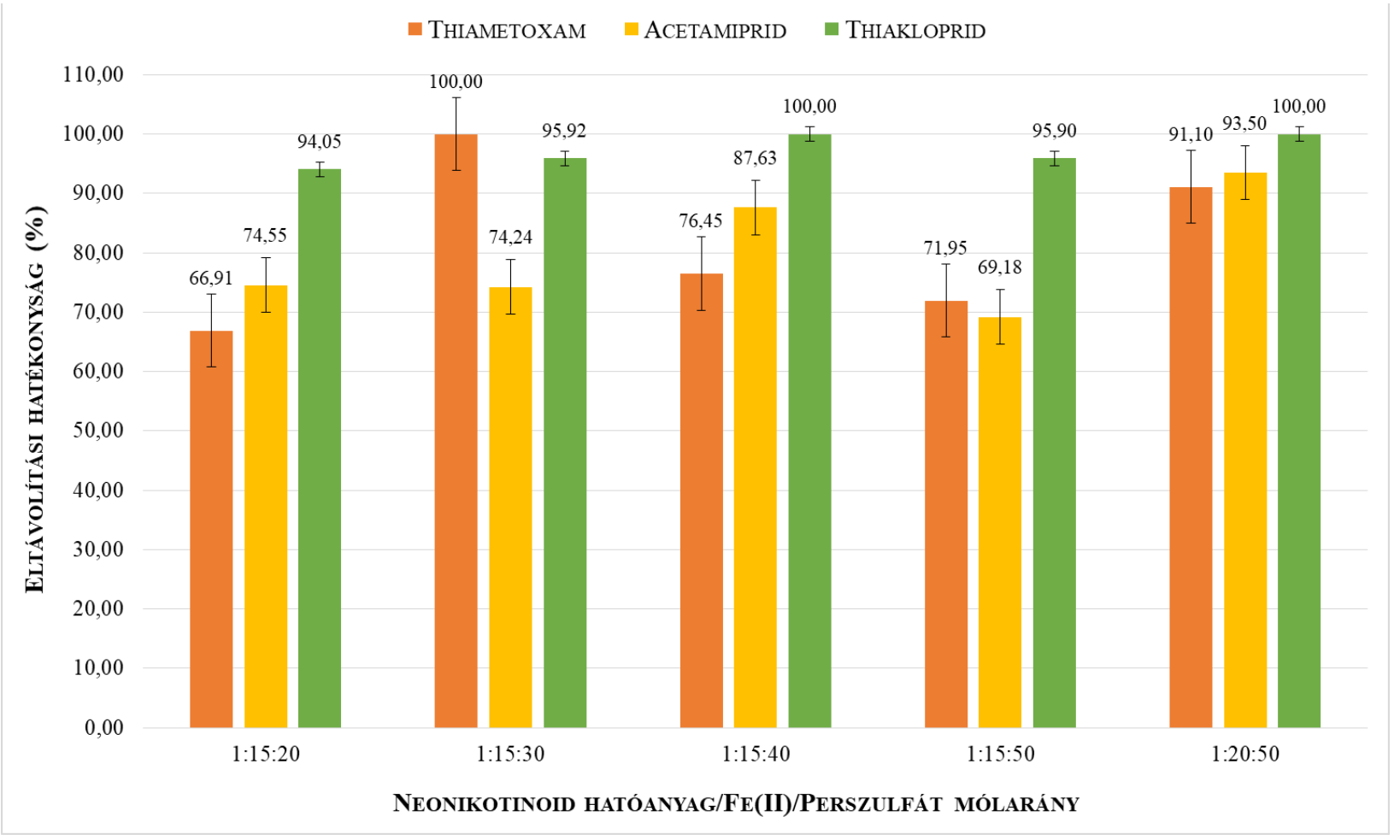

2. ábra Neonikotinoid hatóanyagok eltávolítási hatásfoka perszulfáttal végzett kezelések után

Tapasztalataink alapján az acetamiprid és thiakloprid hatóanyagokra 1:20:50 neonikotinoid/Fe(II)/perszulfát mólarányt alkalmazva érhető el a leghatékonyabb oxidáció a neonikotinoid szennyezők eltávolítására, mellyel 93 \% feletti, és adott esetben teljes mértékű eltávolítási hatékonyság, míg a thiametoxam hatóanyag esetében a 1:15:30 neonikotinoid/Fe(II)/perszulfát mólarány mellett szintén teljes mértékü eltávolítási hatékonyság figyelhető meg (2. ábra).

\section{4. Összefoglalás}

Az oxidációs kísérletekkel célunk volt, hogy az alkalmazott ferrát és perszulfát oxidálószerek segítségével tanulmányozzuk a vizsgált neonikotinoid típusú inszekticidek (thiametoxam, acetamiprid, thiakloprid) oxidatív lebontásának mértékét. A kiindulási koncentrációk csökkenését az általunk fejlesztett HPLC-MS/MS módszer segítségével követtük. A kísérletek során kapott eredmények alapján megállapítható, hogy a ferrát oxidálószerhez képest a kálium-perszulfát-Fe(II) rendszer hatékonyabb oxidálószernek bizonyult már 30 percig kezelt modelloldatokban is.

További előnyök között említhető, hogy az aktivált perszulfát-ion viszonylag olcsó és hatékony oxidálószer, ami alkalmas többek között halogénezett szénhidrogének, aromás szénhidrogének (BTEX), perfluorozott vegyültek, PCB-k, fenolok, gyógyszerhatóanyagok, szervetlen vegyületek és peszticid, mint környezeti szennyezők eltávolítására is. A különböző víz- és szennyvízkezelési, 
remediációs megoldásokban egyre gyakrabban alkalmazott oxidálószer, mivel rendkívül hatékony a szabadgyökös (free radical), ún. advanced oxidation processes (AOPs) kezelések (homogén vagy heterogén katalízis) során. A homogén módszerek savas pH értéken hatékonyak, míg a heterogén katalitikus módszerek széles pH skálán alkalmazhatók. Míg korábban a hidrogén-peroxidot és az ózont alkalmazták oxidálószerként, addig napjainkra a perszulfátok alkalmazása intenzíven terjed, alacsony áruk és hatékonyságuk miatt [11].

Vizsgálatainkban rámutattunk arra is, hogy a ferrát a várttól eltérően nem mutatott kellő mértékű eltávolítási hatásfokot. A kezelési idő növelése, illetve a körülmények változtatásának vizsgálata esetlegesen javíthatja a ferrátos kezelés hatásfokát, de a perszulfáttal végzett kísérletek a választott 30 perces kezelési idő alatt is erélyesen fejtik ki hatásukat, eltávolítva a modelloldat neonikotinoid tartalmának szinte teljes mennyiségét.

Jelen tanulmányban bemutatott kezdeti tapasztalataink jó alapját képezhetik további részletes vizsgálatainknak, mely során a hatóanyagokat együttesen tartalmazó mintaoldatok oxidatív kezelését, az oxidálószerek és aktiválási módszerek további vizsgálatát és kiterjesztését, valamint az oxidatív bomlástermékek azonosítását, illetve a reakciók kinetikai leírását és mechanizmusuk feltárását tűztük ki célul.

\section{Köszönetnyilvánítás}

Méréseinket az IMSYS Mérnöki Szolgáltató Kft. és a Debreceni Egyetem Műszaki Kar Környezetmérnöki Tanszék által koordinált laboratóriumokban végeztük, melyet a GINOP- 2.1.1-152015-00582 számú projekt támogatott.

\section{Hivatkozások}

[1] J.M. Bonmatin - C. Giorgio - V. Girolamiet al. (2015) Environmental fate and exposure; neonicotinoids and fipronil. Environ Sci Pollut Res Int. 22 (1) pp. 35-67.

[2] M. Cristina - J.T. Bartlomiej - Z. Marion - B. Katherine - N. Ralf et al (2018) Unravelling the Molecular Determinants of Bee Sensitivity to Neonicotinoid Insecticides. Current Biology. 28 (7) pp. 1137-1143.e5

[3] H. Chunyan - R. N. Matthew - Z. Xiaoming - D. Morse (2016) Liquid chromatography-tandem mass spectrometry analysis of neonicotinoid pesticides and 6-chloronicotinic acid in environmental water with direct aqueous injection. Analytica Chimica Acta. 925. pp. 43-50.

[4] Z Peng - R. Chao - S. Hongwen - M. Lujuan (2018) Sorption, desorption and degradation of neonicotinoids in four agricultural soils and their effects on soil microorganisms. Science of The Total Environment. 615 pp. 59-69.

[5] S. Tamanna - M. Craig - K. Sonya - D. M. Chris (2018) Neonicotinoid pesticides in drinking water in agricultural regions of southern Ontario, Canada. Chemosphere. 202 pp. 506-513.

[6] Y. Kai - D. Yongxiu L. - Chengbin - H. Qunying - L. Shenglian et al (2018) Kinetics, pathways and toxicity evaluation of neonicotinoid insecticides degradation via UV/chlorine process. Chemical Engineering Journal. 346 pp. 298-306. 
International Journal of Engineering and Management Sciences (IJEMS) Vol. 4. (2019). No. 2

DOI: 10.21791/IJEMS.2019.2.11.

[7] N. Kanari et al. (2013) Synthesis of potassium ferrate using residual ferrous sulfate as iron bearing material. Journal of Physics: Conference Series. 416.

[8] V. K. Sharma (2016) Ferrate $\left(\mathrm{FeO}_{4}{ }^{2-}\right)$ : Environmentally-Friendly Oxidant, Coagulant and Disinfectant for Water and Wastewater Treatment, Symposium 332nd ACS National Fall Meeting, San Francisco.

[9] M Alsheyab et al. (2009) On-line production of ferrate with an electrochemical method and its potential application for wastewater treatment. Journal of Environmental Management. pp. 13501356.

[10] L.W. Matzek - E.K. Carter (2016) Activated persulfate for organic chemical degradation: A review. Chemosphere. 151 pp. 178-188.

[11] W. Stanisław - V. L. Holger - G. Klaudius et al. (2017) Chemistry of persulfates in water and wastewater treatment: A review. Chemical Enginnering Journal. 330 pp. 44-62. 